\title{
When millennials protest
}

\author{
Youth activism in Italy
}

\author{
Massimiliano Andretta and Donatella della Porta'
}

\section{I Young and anti-austerity protests in Italy: an introduction}

Despite the various threats that the Millennial generation faces (from unemployment, to precariousness and uncertainty), many young citizens still engage in politics, though not necessarily through conventional patterns of participation. The economic crisis and the related austerity policies have triggered protest mobilizations in all southern European countries (della Porta et al., 2017). In these, younger generations have played a crucial role. Even though in Italy anti-austerity mobilizations have been led primarily by the old and established trade unions (Andretta, 2018; Andretta and della Porta, 2015), young people have been very much involved in those and in other kinds of protests. This young generation faces markedly different life expectations and/or conditions than the previous ones, and are more seriously threatened by the current economic crisis. In recent research, examining the participation of Millennials in Italy, Poland, Spain and the UK in progressive social movements, the self-identification as a precarious generation was in fact widespread (della Porta, 2019). This makes for a particularly interesting starting point to investigate how these citizens overcome barriers of marginalization, network and develop collective identities.

Despite the fact that young people tend to be overrepresented in unconventional politics, social movement studies have given scant attention to issues of age. There are, however, exceptions, from which we can draw some inspiration for reflecting on the impact of some specific age issues on contentious politics. In this, a first step would be to conceptualize appropriate terms to allow for this reflection. Indeed, youth, cohort and generation are relevant but distinct terms.

First, research on political participation has addressed the role of youth, who are considered in general terms as being less prone to conventional action and more, instead, to protest action. Social movement studies also recognize that protesting requires some biographical availability (McAdam, 1986, 1989). Time availability and lack of responsibilities are considered as relevant. Initially, there was indeed an expectation that growing older (namely, getting a job, marrying, having children) implied less flexibility in the use of one's own time as well as increasing responsibility, which makes protest less likely: it becomes more costly 
and potentially risky for middle-age persons than, for instance, young students. Also, there was an expectation that some material resources could help in buying time flexibility. Research indicates an effect of protesting on those sociobiographical conditions is that individuals may end up delaying the formation of family or pushing towards some types of work rather than others. However, it could not definitively confirm that the taking up of work and family responsibility reduces the commitment to protest. If indeed married life tends to reduce the level of commitment (Corrigall-Brown, 2011), having a full-time job increases participation in voluntary organizations, and even in high-risk forms of participation (Nepstad and Smith, 1999; Wiltfang and McAdam, 1991; Passy and Giugni, 2001). In particular, growing older, getting a job and building a family do not necessarily reduce participation in protest. Recent research noted, however, that some conditions that affect biographical availability can impact the step that precedes the actual choice to participate: the development of positive motivations towards protest seems to decline for married people and full-time or part-time employees (Beyerlein and Hipp, 2006). At the micro-level, student activism has been linked to specific characteristics of younger people, such as the availability of time and limited responsibilities, but also enthusiasm, idealism and exposure to new ideas (Lipset and Altbach, 1967). Students have been presented as spoiled, highly emotional, rebellious, unable to handle ambiguity, devoted to an ethic of absolute ends, irreverent, adventurist or radicalistic (Lipset, 1971).

Issues of age have been addressed in demographic analysis that point at the relevance of the size of the youth cohort on the amount and forms of protests. As Goldstone (2015: 148) summarized:

An age cohort is simply a group of people of roughly the same age, who were born in a particular period. In the United States, it has become common to refer to those born between 1945 and 1960 as the 'baby boomers'; those born from 1960 to 1980 as 'Generation X;' and those born from 1980 to 2000 as 'Millennials'. However, cohorts do not always vary or form systematic groups (Gen $\mathrm{X}$ in the United States is known mainly for being very diverse and hard to classify). Rather, their significance has more to do with whether a cohort experienced a major shift in its size, education, or experience relative to other cohorts.

The Arab Spring ${ }^{2}$ has, in this sense, been considered as developing in an environment characterized by a large presence of young people. In fact, the socialization of new generations is considered as less challenging as:

...when the numbers of people in society are stable or changing slowly enough for growth in the economy and institutions to accommodate the change. However, rapid change in the size of cohorts, or of particular social groups, can easily disrupt this process and place great strains on institutions. (Goldstone, 2015: 150) 
Cohorts acquire more of an impact on collective action when they go through some shared, important event that contributes to shaping their norms, values and behaviour in their future lives. In the conceptualization from Mannheim (1952: 292), we are therefore talking of a political generation. That is 'a particular kind of identity of location, embracing related "age groups" embedded in a historical-social process'. In particular, the 1968ers were named as a generation that had come of age during a moment of affluence and reduction of inequalities, endowed with 'postmaterialist' values (Inglehart, 1977) and broad political interests (Downtown and Wehr, 1997). Student activists of the 1960s were also said to be more likely to be children of left-wing fathers, often intellectuals, with middle-class (or even upperclass) families with permissive and critical education (Lipset, 1971). Expressing the moral dissonance or frustration of a generation, the young activists criticized nevertheless their parents for their unfulfilled promises (Giugni, 2004).

With the aim of contributing to the debate on the impact of age (youth, cohort, generation) on contentious politics, our chapter focuses on the dynamics of the political commitment of young Italians. The particular cohort is defined as those aged between 14 and 40 years, involved in at least one collective mobilization between 2010 and 2011. The selected age cohort is intended to capture a generation facing a very different type of life expectations and/or conditions than the previous ones, and they are more seriously threatened by the ongoing economic crisis. By relying on data from several surveys carried out during protest events on social, economic and labour issues from 2010 to 2011, a period in which the economic crisis spread and deepened in Italy, we single out differences and similarities between younger and older generations on those aspects that social movement studies underline as crucial in explaining individual participation, namely grievance and emotion, collective identity and network embeddedness (della Porta and Diani, 2006).

The article is structured as follows: in the following section, we present the research method undertaken for this study. Following which, in the literature review we elaborate on the dimensions we decided to focus on, dealing respectively with the generational composition of demonstrations selected, the type of grievances and emotions, collective identities, and, finally, network embeddedness. In the conclusion, we summarize the most important findings and suggest some tentative explanations in the Italian case.

\subsection{The empirical research}

In addressing the previously mentioned questions, we will use data on surveys of protest demonstrations in Italy carried out by Cosmos (Centre on Social Movement Studies) at the European University Institute within an international consortium coordinated by Bert Klandermans and Stefaan Walgrave, on a project named Contextualizing Contestation (see www.protestsurvey.eu).

For this chapter, we restricted the analysis to four types of demonstrations in Italy: the traditional labour day demonstration (Florence 2011), a typical 
anti-austerity protest (Rome 2012), an anti-neoliberal type of protest (Florence 2012), and finally, a new type of protest directly involving the younger generation (the EuroMayday in Milan 2011). Demonstrators were sampled randomly and given a questionnaire to mail back. About 1,000 questionnaires were distributed at each demonstration, with an average return rate of $20 \%{ }^{3}$

Using the surveys conducted from the selected Italian demonstrations, this article focuses on the analysis of the 'younger generation' involved in them, operationalized by selecting those demonstrators born after 1985, thus, being 25 years old or less at the moment of the selected demonstrations, compared with the 'older generations': those born between 1970 and 1984, (between 40 years and 26 years old), those born between 1955 and 1969 (between 55 and 41 years old), and those born in 1954 or earlier (over 55 years old). Our youngest generation category includes demonstrators being 24 years old on average (the standard deviation is 2.4 years); the second generation, those protestors being on average 34 years old (the standard deviation is 4.3 years); the third generation, on average 50 years old (the standard deviation is 4 years), while in the last and oldest generation those on average 62 years old (with a standard deviation of 5.5 years).

\subsection{Presence and social composition of the younger generations in Italian anti-austerity demonstrations}

Research on political participation has long suggested that political participation increases with social centrality. The argument is that a higher socio-economic status is predictive of more political participation. The normative problems involved in this selectivity were increased by the non-representativeness of those who participated: in fact, higher levels of participation were observed, ceteris paribus, for the better educated, middle class, men, middle-age cohort, married people, city residents, ethnic majority and citizens involved in voluntary associations (Milbrath and Goel, 1977; Lagroye, 1993). Usually, higher social status implies in fact more material resources (but also free-time) to invest in political participation, as well as a higher probability of being successful in their careers (via personal relationships with powerful individuals) and especially a higher sense of personal achievement. Psychological disadvantages overlap with social disadvantages, reducing the perception of one's own 'droit de parole' (Bourdieu, 1979: 180). If participation responds to demands for equality, it tends however to reproduce inequalities since:

...any individual participates, at least potentially, with the differential (or unequal) coefficient (if we do not want to use the word 'privilege', that would have an ancien régime flavour) that characterizes his/her position in the system of private interests (Pizzorno, 1966: 90).

Social movement studies have challenged this elitist vision by presenting protest as a resource of the powerless (Lipsky, 1970). They noted indeed that those 
who protest present some different characteristics than those who use conventional forms of political participation: if the middle classes vote more, workers strike more often; and if those in middle age are more present in party-related activities, students occupy their schools and universities (della Porta, 2015). Nevertheless, social movement studies also recognized that protesting requires some biographical availability (McAdam, 1986, 1989). First, time availability and responsibilities are considered as relevant. Initially, there was indeed an expectation that growing older and the sociobiographical conditions that this usually entails (i.e. getting a job, marrying, having children) implied less flexibility in the use of one's own time as well as increasing responsibility, which makes protest less likely. Even though research indicated an effect of those factors on protesting, and, indeed, married life tends to reduce the level of commitment (Corrigall-Brown, 2011), having a full-time job, however, increases participation in voluntary organizations, even in high-risk forms of participation (Nepstad and Smith, 1999; Wiltfang and McAdam, 1991; Passy and Giugni, 2001). In particular, growing older, getting a job and building a family do not necessarily reduce participation in protest.

Our research indicates that the presence of the youngest generation, in the four types of demonstrations that occurred in the period of crisis, was quite strong, accounting for $18 \%$ of the full sample, on average. However, if we look at its presence across the types of demonstrations (Table 2.1), we see that the youngest generation were most concentrated in what we called 'youth against the crisis' type of protest marches (27\%) and in the anti-neoliberal type (23\%). Meanwhile, about $16 \%$ demonstrated in the No Monti ${ }^{4}$ rally and as few as $2 \%$ in the traditional Labour Day demonstration. Both the No Monti day and the Labour Day demonstrations were dominated instead by the two oldest generations, while the second generation showed patterns of presence across demonstrations similar to the youngest one.

Moreover, only $11.5 \%$ of marchers belonging to the youngest generation said they had participated in their first demonstration during in the proceeding twelve months, whilst half had participated in more than one and less than five demonstrations, and the rest had protested more than six times. Finally, against the expectation of the social centrality hypothesis, $17 \%$ of them had participated at

Table 2.I Age cohorts across types of demonstrations

\begin{tabular}{llllll}
\hline Age Cohorts & $\begin{array}{l}\text { Euromayday, } \\
\text { Milan }\end{array}$ & $\begin{array}{l}\text { Mayday, } \\
\text { Florence }\end{array}$ & $\begin{array}{l}\text { No Monti Day, } \\
\text { Rome }\end{array}$ & $\begin{array}{l}\text { Florence } \\
10+10\end{array}$ & Total \\
\hline Till 26 & $26.8 \%$ & $19 \%$ & $16.3 \%$ & $23.7 \%$ & $17.7 \%$ \\
$27-40$ & $53.7 \%$ & $7.6 \%$ & $19.5 \%$ & $29.0 \%$ & $27.1 \%$ \\
$41-55$ & $12.2 \%$ & $42.9 \%$ & $39.5 \%$ & $20.6 \%$ & $29.5 \%$ \\
$56+$ & $7.3 \%$ & $47.6 \%$ & $24.7 \%$ & $26.7 \%$ & $25.7 \%$ \\
Total & 123 & 105 & 190 & 131 & 549 \\
\hline
\end{tabular}

$N=549 ;$ Cr.s V: presence across types of demonstrations Italy, 0.29 ; significant at $0.00 \mathrm{I}$ level. 


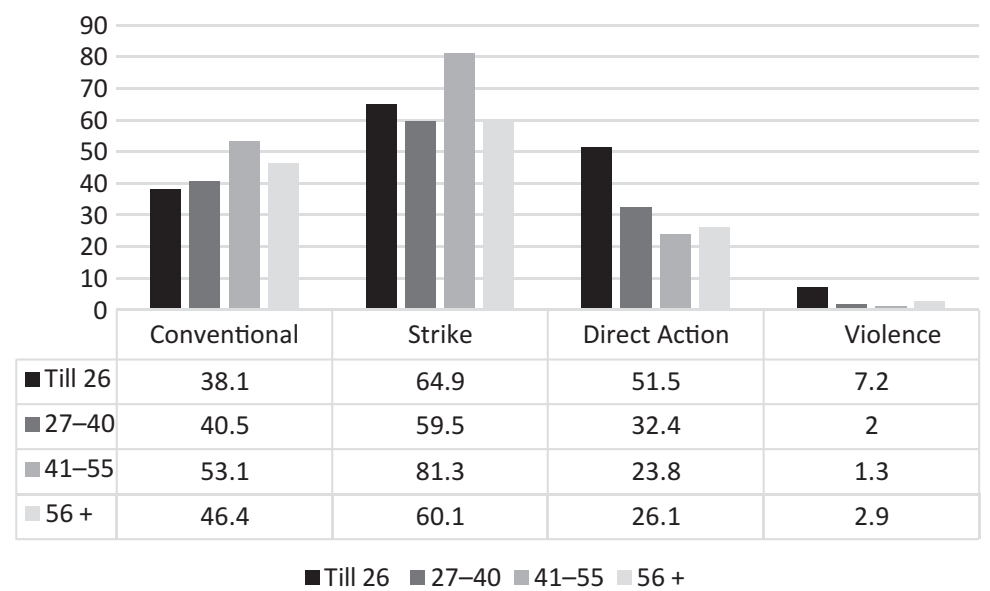

Figure 2.I Age cohorts by types of protest actions used in the past. (Note: We recoded the forms of action reported in the questionnaire as follows: conventional [contacted politician, government or local government official; signed a petition, donated money to a political organization or group, and worn or displayed a campaign badge or sticker]; strike [joined a strike]; direct action [blockade, occupation, civil disobedience]; and violent [any violent action against things and people]. $N=543$; Cr.s V: across conventional forms, 0.12 , significant at 0.05 level; across strike, 0.20 , significant at $0.00 \mathrm{I}$ level; across direct actions, $0.2 \mathrm{I}$, significant at $0.00 \mathrm{I}$ level, across violent forms, 0.12 , significant at 0.05 level.)

least 11 times in the last 12 months against about $14 \%$ of the central generations and $18 \%$ of the oldest one.

Besides participation in protest marches, the youngest generation shows a high degree of commitment to various types of protest actions, and privileges the most radical ones (Figure 2.1).

Gender distribution is more balanced in the youngest generation (53\% vs. an average of 47\%). As for occupational distribution, those belonging to the youngest generation were most often - but not exclusively - students (47\%), 13\% were unemployed or between jobs, $21 \%$ employed part-time and $8 \%$ were full-time. It is not surprising that the youngest generation is the most educated, with about $90 \%$ of its members being at least graduates (first stage of tertiary), against an average of $65 \% .^{5}$

\subsection{Grievances and emotions}

Grievances theories have long been challenged by more recent approaches to social movement studies (Klandermans, 1997), suggesting that what is to be analysed is more how grievances are translated into action than grievances per se. 
Whilst it is certainly a valid suggestion, it does not mean that we should completely dismiss the analysis of grievances. As van Stekelemburg and Klandermans (2013: 888) have recently argued, 'at the heart of every protest are grievances, be they, experience of illegitimate inequality, feelings of relative deprivation, feelings of injustice, moral indignation about some state of affairs, or a suddenly imposed grievance'. Social psychologists are among the few who continued to pay attention to grievances, by underlining how together with other dimensions, the relations between grievances and emotions is worth analysing to explain collective action. In particular, they point at how grievances trigger a sense of injustice, which often produces indignation, which in turn is transformed in anger (Klandermans et al., 2008).

There has recently been a recognition that social movement politics is passionate politics (Goodwin et al., 2001), as 'participants in rituals communicate whole complexes of ideas and embodied feelings' (Barker, 2001: 188). Social movements are certainly rich in emotion: 'Anger, fear, envy, guilt, pity, shame, awe, passion, and other feelings play a part either in the formation of social movements, in their relations with their targets...and in the life of potential recruits and members' (Kemper, 2001: 58). Different typologies have been built that distinguish emotions that address a specific object from more generic ones, or short-term versus long-term emotions, or reciprocal versus shared emotions (Goodwin et al., 2001). Emotions of trauma (grief, shame, helpless anger) are distinguished from emotions of resistance (pride, happiness, love, safety, confidence, righteous anger) in research on the movement against child sexual abuse (Whittier, 2001: 239). Feelings such as anger, outrage or fear can be particularly relevant in recruitment; indignation, pleasure, and pride can reinforce commitment (Goodwin et al., 2001). Emotions are embedded in a context, where social rules define the proper emotions to feel and the proper way to express them. In fact, emotions are produced in social interactions: rituals produce emotions, and emotions interact with cognition in determining an individual's behaviour.

Social movements as well as protest events tend to transform emotions (e.g. transforming shame into solidarity), or to intensify them (Collins, 2001: 29). Successful rituals produce collective effervescence and group solidarity, strengthening the emotional energy. For example, some protest rituals and language helped transform shame into pride in the gay and lesbian communities (Gould, 2003; see also chapter 4 in this volume). In particular, social movements transform emotions by modifying the everyday relations the 'old' emotions were attached to (Calhoun, 2001: 55). Specific groups or specific environments nurture master emotional paradigms (or habitus) that define appropriate emotions (della Porta and Giugni, 2009).

In order to investigate grievances, we focus on their more political component, by looking at protestors' attitudes toward the political system and main political actors, as well as on their levels of satisfaction with the democracy in their country. Institutional trust is generally very low, showing similarities in the political grievance across generations: only $2.5 \%$ of protestors trust quite 
or very much national governments and 5\% the parliament, with no significant differences across age cohorts. But, if only about $6 \%$ trust political parties, the percentage rises to $11 \%$ amongst the oldest protestors and decline to a mere 3\% amongst the two cohorts of young protestors. Trade unions and the EU are more trusted, however, on overage by respectively $24 \%$ and $27 \%$ of protestors. If trust in EU is similar across generations, trade unions are much more trusted by the two older generations (34\% and 25\%) than by the young protestors (about 17\%). ${ }^{6}$

Satisfaction with democracy is also very low in general with no statistical differences between generations: on a scale from 0 (not satisfied at all) to 10 (very much satisfied), all participants' answers scored only about 2.4 , while the average of the youngest generation was 2.2.

Dissatisfaction with democracy calls into question the role of political parties, which were not trusted at all. However, whilst all generations were not trusting of political parties in general, most felt at least quite close to a specific party (about $75 \%$, with no statistical differences across cohorts).

The attitude towards elections did not differ much between generations either: about $58 \%$ of the youngest and the following two generations disagreed or strongly disagreed with the statement, 'voting is useless in this country', while the percentage increased to $75 \%$ among protestors of the oldest generation. ${ }^{7}$ What is more, about $98 \%$ of the protestors in our sample voted for one party in the last elections before the demonstrations, mostly for the centreleft and radical-left parties. Therefore, despite the mistrust expressed in relation to political actors and institutions, and the dissatisfaction with the Italian democracy, all protestors seemed to consider elections an important tool to put their claims forward.

As far as emotions are concerned, our questionnaire included a battery of four items, which sought to measure the emotional side of demonstrators' mobilization. Respondents were asked to express how angry, worried, frustrated or fearful they felt when they thought of the problems they were protesting about, using a scale from 1 (not at all) to 5 (very strongly). If we look at the percentages of those feeling each emotion 'very strongly', protestors all felt worried about the current situation (about $70 \%$, with no statistical differences between generations), but a little fearful (only $22 \%$ on average, with no statistical differences), the youngest generation felt a bit more frustrated (50\% against the average of $42 \%$ ), but surprisingly, a bit less angry (57\% against $63 \%$ in average). ${ }^{8}$

On the other hand, even when worried and angry, our protestors had not lost their belief that they could make a difference, and have in impact on the current situation: about $70 \%$ on average declared that they have an impact individually, but as many as $80 \%$ expressed the belief that 'groups have an impact' and that 'international cooperation among groups has an impact'. Again, no remarkable generational differences could be found on this sense of individual and collective efficacy.

To sum up, the youngest generation protesting in Italy in times of crisis do not differ too much in terms of grievances and emotions from the older 
generations. They were all indignant towards the political system, a system in which they were probably considered unable to deal with their life problems, and 'deaf' to their voice. The youngest protestors trusted institutions and political actors a bit less, but mistrust was widespread across all generations. The very low trust in political parties and representative institutions is linked to their strong dissatisfaction with democracy. However, if this makes them particularly angry and worried, it had not undermined their confidence on the impact of their voice.

\subsection{Is there a generational collective identity in Italy?}

Alessandro Pizzorno (1966) noted long ago that the characteristics of political participation are rooted in the systems of solidarity that are at the basis of the very definition of interest: interests can in fact be singled out only with reference to a specific value system, and values push individuals to identify with wider groups in society, providing a sense of belonging to them and the willingness to mobilize for them. From this perspective, participation is an action in solidarity with others that aims at protecting or transforming the dominant values and interest systems. The process of participation requires therefore the construction of solidarity communities within which individuals perceive of themselves and are recognized as equals. Political participation itself aims at this identity construction: before mobilizing as a worker, an individual has to identify herself as a worker and feel that she belongs to a working class. Identification as awareness of being part of a collective $u s$ facilitates political participation. As Pizzorno (1966: 109) stated, in fact, the latter 'increases (it is more intense, clearer, more precise) when class consciousness is high'. Participation is therefore explained not only by individual resources, but also by collective resources.

In fact, recent research has looked at the shift from individual to group identities, and then the politicization of such identities. In social movement studies, collective identification is expected only if there is awareness of the fact that one's own destiny is in large part linked to material conditions, while the lack of such awareness is defined as false consciousness (Snow and Lessor, 2013).

Identity formation is a complex process, which is difficult to operationalize. As far as our data are concerned, relevant indicators included in the questionnaire are identification with other demonstrators and the organizations staging the demonstrations, as well as various motivations, values and norms that pushed participants into the street. Our research data indicates that the youngest generation of protestors identifies less than the other generations, especially the oldest ones, both with participants (57\% identify 'quite', or 'very much' against $67 \%$ on average; Cr.s $\mathrm{V}=0.21$, significant at 0.001 level) and with the organizations staging the demonstration $(56 \%$ vs. $60 \%, \mathrm{Cr} . \mathrm{V}=0.19$, significant at 0.001 level).

With respect to motivations, the youngest generation seemed less motivated to participate in the selected demonstrations 'to express solidarity'; 'to press politicians'; because they 'feel morally obliged'; and because they want 'to raise awareness' 


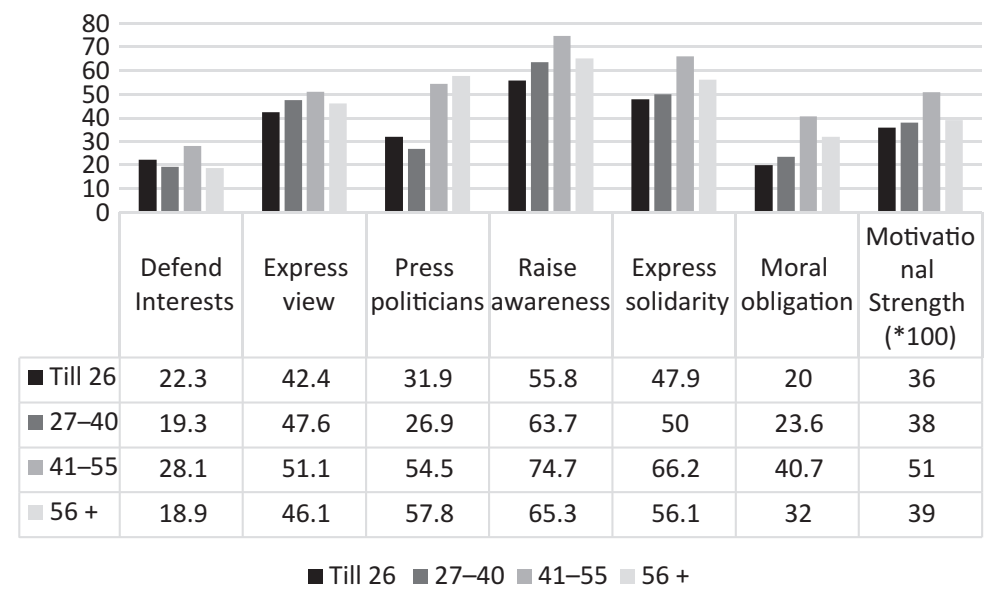

Figure 2.2 Age cohorts by motivations for protesting. (Note: $N$ : $469-505$. Cr.s $V$ is significant for 'press politicians' [0.28, at 0.001 level]; rise awareness [0.13, at 0.05 level], 'express solidarity' [0.15, at 0.01 level], and 'moral obligation' $[0.18$, at 0.001 level]. The ETA of the means calculated on the indicator of 'motivational strength' is 0.21 , significant at 0.00 I level.)

in the public opinion; while no significant differences are found when protestors are motivated 'to express their view' and 'to defend their interests' (Figure 2.2).

If we build an indicator of 'motivation strength', ranging from 0 (no motivation at all) to 1 (strongly motivated), ${ }^{9}$ we notice that against a mean of 0.42 , the youngest generation scores only 0.36 , while the most strongly motivated generation is composed by the protestors who were at least 50 years old at the time of the selected demonstrations, with a score of 0.51 (Figure 2.2).

If we look instead at the self-location of the different generations on a classical left-right scale, we notice that the youngest generation of protestors, together with those of the second youngest generation, are less radical than the others: in the $0-10$ left-right scale, in fact, young protestors score on average 1.3 while the two oldest one between 0.7 and $0.8 .{ }^{10}$

Summarizing, it seems that the youngest generation had a weaker collective identity than the other ones, at least as far as identification with other demonstrators (individually or in group) is concerned. The old generations were more radical, identified more with collective identities and were more motivated.

\subsection{Networks and embeddedness}

A different set of explanations for participation looks at embeddedness in social networks (Diani, 1992; della Porta, 2013). The main assumption is that participation in protests requires supporting networks that provide positive incentives, not only 
in affective terms but also in cognitive ones. Networks, which are relevant for the explanation of differential political participation, are those that provide information about protest events as well as emotional support. In line with the literature on social capital, these networks are expected to provide norms of reciprocity and reciprocal trust that are relevant for collective action. Embeddedness helps overcome the freerider phenomenon by providing a sense of commitment as well as social control. So much so, that the single most relevant factor in explaining participation in protests was whether one had been asked to participate (Schussman and Soule, 2005).

The presence of dense but informal networks distinguishes social movements from other collective actors, which instead have clear organizational boundaries. In social movements, individuals and organizations, while keeping their autonomous identities, engage in sustained exchanges of resources oriented to the pursuit of a common goal (della Porta and Diani, 2006: 21).

In a cross-national study on protest participation based on the World Values Survey, Russell Dalton and his colleagues (Dalton et al., 2010) noted that 'involvement in social groups creates networks for recruitment in political life' (ibid.: 59). In fact, 'social group membership are strong and significant predictors of protest' (ibid.: 67). Similarly, in research on immigrants' mobilization, Klandermans et al. (2008) observed that participation in associations was very highly correlated with experiences with protest, as well as with other dimensions connected with protest, such as identification with an ethnic group, sense of efficacy and feelings of injustice.

To operationalize network embeddedness, we use three sets of variables: the first set included whomever respondents were protesting with (if alone, with their family, with friends and acquaintances, with colleagues or with other members of the organization they belong to); the second, the most important channels of information through which protesters knew about the demonstration (mainstream or alternative media, family, informal, work or organizational channels); the third, their membership in different types of organizations.

The first set of variables has been aggregated by considering a scale of network embeddedness. This means that if a protesting individual was accompanied by friends and acquaintances, he/she is included in external networks; if he/she was with colleagues, he/she would be put in place of work/study networks; and if he/ she was with other members of an organization, he/she would be considered part of an organizational network.

The data presented in Figure 2.3 shows that the youngest generation of protestors were more embedded in informal networks, such as friends, in networks based on the place of work or study, but also in organizational networks. The only relevant difference with the other generations seems to be that they rely more on relations built in their places of study, compared with relations in places of work of the older generations.

As far as the channels of information are concerned, the most important, and indeed interesting, difference refers to the much higher use of online alternative media and informal networks by the youngest generation (Figure 2.4). It is to be 


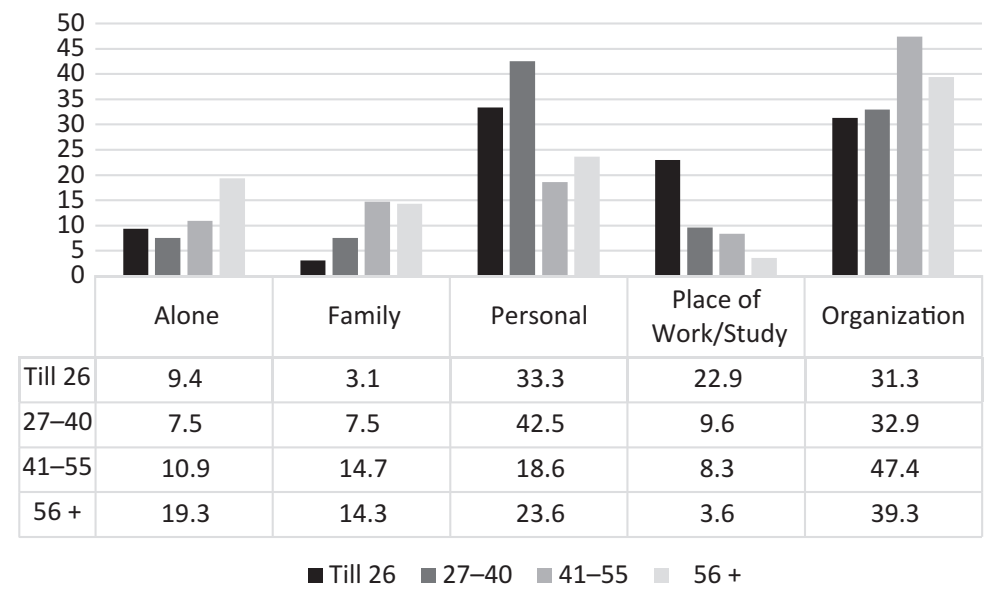

Figure 2.3 Network embeddedness of the different generations. (Note: N: 538, Cr. s V: 0.20 ; significant at 0.001 level.)

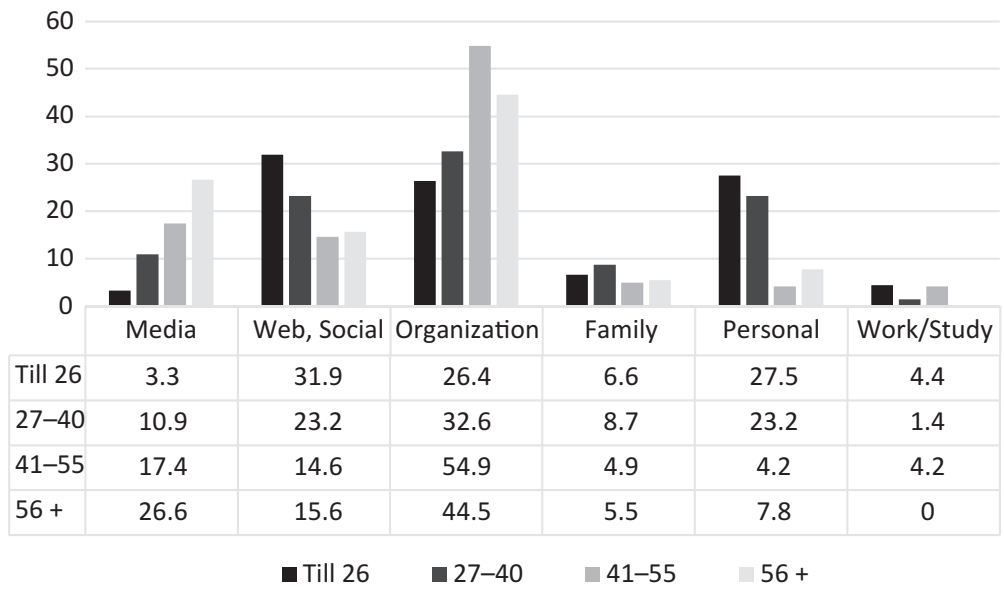

Figure 2.4 Most important channels of information across generations. (Note: $\mathrm{N}=50 \mathrm{I}$; Cr.s V: 0.24 , significant at 0.00 I level.)

remarked that the youngest protestors were less likely to use traditional media compared with the older ones. Moreover, against an average of $41 \%$ of protestors getting informed through organizational channels, only $26 \%$ of the youngest ones do so.

Finally, as far as organizational membership is concerned, $25 \%$ of the youngest generation participants were members of the organizations staging the demonstrations, against an average of $42 \%{ }^{11} ; 37 \%$ (vs. $27 \%$ on average) were not members of any organization at the time of the demonstration or in the 12 months 


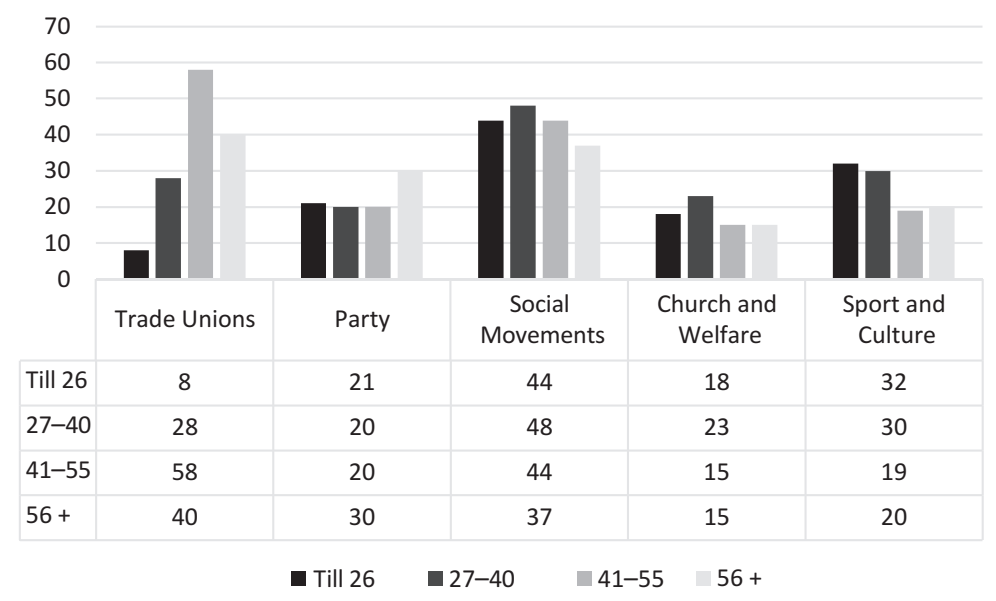

Figure 2.5 Age cohorts by type of organizational membership. (Note: N: 549; Cr.s V is significant for membership in trade unions [0.36, at $0.00 \mathrm{I}$ level] and in sport and culture organizations $[0.13$, at 0.05 level].)

previous; $27 \%$ (vs. 29\% average) were members of a single organization; $26 \%$ (vs. $32 \%$ average) were members of two or three organizations; and $11 \%$ (as on average) were members of more than three. ${ }^{12}$

If we look at the types of organizational membership (Figure 2.5), we notice that the youngest generation were prevalently members of social movement organizations or sports and culture organizations. Surprisingly, $21 \%$ of the youngest cohort were members of a political party - only the oldest generation show more party membership - while $18 \%$ stated that they were members of church or welfare organizations. Trade unions attracted more of the older generations, and though it comes as no surprise that only $8 \%$ of the youngest protestors were among their members, it is of some interest to note the relatively low score in this type of membership of the protestors from the 1970 to 1984 cohort, confirming the decline of unionization among young workers.

To sum up, the different generations were embedded in different types of networks. For the youngest generation of protestors, these were mostly informal and based on new, online, types of communication, whereas the older cohort were more formally embedded in organizations.

\subsection{A generational comparison: some conclusions}

In conclusion, we have observed that young people have participated in different marches on austerity issues, bringing with them experiences of social groups that are outside of the labour market. While similar to other cohorts in their mistrust 
for political institutions and trust instead in protest as a form of political participation, the young people we surveyed who had taken part in the anti-austerity protests seemed to have some specific characteristics in terms of a lower degree of collective identification and organizational embeddedness, and instead a higher degree of informal and 'virtual' connectedness.

These results seem, therefore, to resonate with those of recent research on youth mobilization in protest. From the generational point of view, research, in particular in the United States, has often lamented that, in contrast with the generation that came of age during World War II that was highly engaged in a duty-based citizenship (Putnam, 2000; Dalton, 2009), more recent generations have been considered as less engaged in conventional forms of political and civic activities (Fisher, 2012; Caren et al., 2011: 147). As Fisher (2012) noted, however, several recent studies (again, in the United States) observed significant changes in the political participation of young people, who are said to protest at least as much as earlier cohorts, even if alternative forms of commitment, such as consumer activism, are increasingly popular amongst young people (e.g. Nonomura, 2016) and the same is true for petitions (Caren et al., 2011: 147). The social and political engagement of young people is not necessarily declining, but changing form (Earl et al., 2017). So, 'it is not that youth are disengaged, but rather that they do not engage in the same way that "dutiful" generations have' (Earl et al., 2017: 1). In particular, young people's participation has developed towards 'engaged citizenship' in volunteering as well as embedding activism in their everyday life. Moreover, a new generation has been singled out - often called 'Millennials' (Connery, 2008; Dalton, 2009). Referring to this generation, a shift has been observed in terms of, 'an unmistakable expansion of youth interest in politics and public affairs' (Sander and Putnam, 2010: 11), in the forms of volunteering but also of voting. In fact, '2008 provides a baseline from which participation may expand as members of the millennial generation finish their studies, begin a career, purchase a home, and share the other life experiences that foster attention to government and politics' (Dalton, 2009: 196). The so-called Millennials have been characterized as carrying specific values: pluralism and tolerance, even if with low trust in political institutions. Research on political socialization pointed at the tensions between the supply in terms of social movement organizations and the generational taste for horizontal organizing (Earl et al., 2017).

Today, researchers have addressed the Millennials as a generation that faces indeed very different life expectations and/or conditions than the previous ones, and it is more seriously threatened by the current economic crisis. As research in Europe has observed, as young people mobilized en masse in protest campaigns against austerity, for gender rights or territorial concerns, protest repertoires and frames tend to be adapted to a condition described as not only as socially precarious, but also as politically betrayed and civically repressed (della Porta, 2018). This makes it particularly interesting to continue investigating how these citizens overcome barriers of marginalization, network and develop collective identities. 


\section{Notes}

1 As some assessment process requires formal attribution, we declare that Donatella della Porta is responsible for sections 'Young and anti-austerity protests in Italy: an introduction' and 'A generational comparison: some conclusions', while Massimiliano Andretta for the remaining sections.

2 The sudden and contagious mobilization by young citizens in many North Africa and Middle-East countries in the period between 2010 and 2011 aimed at democratizing their political systems (Abdih, 2011; della Porta, 2017).

3 For detailed information on the sample methodology see van Stekelenburg et al. (2012) and Andretta and della Porta (2014).

4 Professor Mario Monti was at the time prime minister of the new take-care government formed after Silvio Berlusconi resignation in 2011.

$5 N=548$; Cr.s V: across level of education, 0.25 , significant at 0.001 level.

6 Cr.s V: only across trust in political parties and trade unions, age cohorts show statistical differences ( 0.14 and 0.15 , respectively, and both significant at 0.01 level).

7 N: 535; CR.s V, 0.13, significant at 0.01 level.

$8 \mathrm{~N}$ : 431-496; Cr.s V is significant only for 'Angry' -0.16 at 0.001 level.

9 The indicator is built by dichotomizing each type of motivation getting value ' 1 ' if the participant strongly agrees with the relative item, then normalizing the sum of all motivations dummies. The data in Figure 2.2 concerning this indicator are shown by multiplying it by 100 .

10 The scale ranges from 0 (left) to 10 (right). Thus, the closer to 0 participants place themselves, the more leftist they are. $N=529$; ETA: 0.18, significant at 0.001 level. It is worth noticing that young Italian protestors appear to be much less radical than other young protestors from Southern Europe (Andretta and della Porta, 2015; see also della Porta et al., 2017).

$11 N=515$; Cr.s V: 0.28, significant at 0.001 level.

$12 N=519$; Cr.s V is not significant.

\section{References}

Abdih, Y. (2011). Arab Spring: Closing the Jobs Gap. High youth unemployment contributes to widespread unrest in the Middle East Finance \& Development, Finance \& Development (International Monetary Fund), June.

Andretta, M. (2018). Protest in Italy in times of crisis: A cross-government comparison. South European Society and Politics, 23(1), 97-114.

Andretta, M. and della Porta, D. (2014). Surveying protestors: Why and how. In: della Porta, D. (ed) Methodological Practices in Social Movement Research. Oxford: Oxford University Press, 308-334.

Andretta, M. and della Porta, D. (2015). Contentious precarious generation in anti-austerity movements in Spain and Italy. Revista OBETS, 10(1), 37-66.

Barker, C. (2001). Fear, laughter, and collective power: The making of solidarity at the Lenin Shipyard in Gdansk, Poland, August 1980. In: Goodwin, J., Jasper, J.M. and Polletta, F. (eds) Passionate Politics. Chicago: University of Chicago Press, 175-194.

Beyerlein, K. and Hipp, J.R. (2006). A two-stage model for a two-stage process: How biographical availability matters for social movement mobilisation. Mobilisation, 11(3), 299-320.

Bourdieu, P. (1979). La distinction. Paris: Minuit.

Calhoun, C. (2001). Putting emotions in their place. In: Goodwin, J., Jasper, J.M. and Polletta, F. (eds) Passionate Politics. Chicago: University of Chicago Press, 45-57. 
Caren, N., Ghoshal, R.A. and Ribas, V. (2011). A social movement generation: Cohort and period trends in protest attendance and petition signing. American Sociological Review, 76, 125-151.

Collins, R. (2001). Social movements and the focus of emotional attention. In: Goodwin, J., Jasper, J.M. and Polletta, F. (eds), Passionate Politics. Chicago: University of Chicago Press, 27-44.

Connery, M. (2008). Youth to Power: How Today's Young Voters Are Building Tomorrow's Progressive Majority. Brooklyn, NY: Ig Publishing.

Corrigall-Brown, C. (2011). Patterns of Protest: Trajectories of Participation in Social Movements. Stanford, CA: Stanford University Press.

Dalton, R., van Sickle, A. and Weldon, S. (2010). The individual-institutional Nexus of protest behaviour. British Journal of Political Science, 40(1), 51-73.

Dalton, R.J. (2009). The Good Citizen: How a Younger Generation Is Reshaping American Politics. Washington, DC: CQ Press.

della Porta, D. (2013). Can Democracy Be Saved? Participation, Deliberation and Social Movements. Cambridge: Polity Press.

della Porta, D. (2015). Social Movements in Times of Austerity: Bringing Capitalism back into Protest Analysis. Cambridge: Polity Press.

della Porta, D. (2019). Deconstructing Generations: Concluding Remarks. American Behavioral Scientist, 63(11), 1578-1596.

della Porta, D., Andretta, M., Fernandes, T., O’Connor, F., Romanos, E. and Vogiatzoglou, M. (2017). Late Neoliberalism and Its Discontents in the Economic Crisis. London: Palgrave.

della Porta, D. and Diani, M. (2006). Social Movements: An Introduction. 2nd ed. Oxford: Blackwell Publishing.

della Porta, D. and Giugni, M. (2009). Democracy from below: Activists and institutions. In: della Porta, D. (ed) Another Europe. London: Routledge, 86-109.

Diani, M. (1992). The concept of social movement. The Sociological Review, 40, 1-25.

Downton, J. Jr. and Wehr, P. (1997). The Persistent Activist: How Peace Commitment Develops and Survives. Boulder, CO: Westview.

Earl, J., Maher, T.V., and Elliott, T. (2017), Youth, activism, and social movements. Sociology Compass, 11(4), 1-14.

Fisher, D.R. (2012). Youth political participation: Bridging activism and electoral politics. Annual Review of Sociology, 38, 119-137.

Giugni, M.G. (2004). Personal and biographical consequences. In: Snow, D.A., Soule, S.A. and Kriesi, H. (eds) The Blackwell Companion to Social Movements. Oxford: Blackwell Publishing, 489-507.

Goldstone, J.A. (2015). Demography and social movements. In: della Porta, D. and Diani, M. (eds) The Oxford Handbook of Social Movements. Oxford: Oxford University Press,146-158.

Goodwin, J., Jasper, J.M. and Polletta, F. (eds). (2001). Passionate Politics: Emotions and Social Movements. Chicago: University of Chicago Press.

Gould, D.B. (2003). Passionate political processes: Bringing emotions back into the study of social movements. In: Goodwin, J. and Jasper, J. (eds) Rethinking Social Movements. Lanham, MD: Rowman \& Littlefield, 282-302.

Inglehart, R.F. (1977). The Silent Revolution. Princeton: Princeton University Press.

Kemper, T.D. (2001). A structural approach to social movement emotions. In: Goodwin, J., Jasper, J.M. and Polletta, F. (eds) Passionate Politics. Chicago: University of Chicago Press, 58-73. 
Klandermans, B. (1997). The Social Psychology of Protest. Oxford: Blackwell.

Klandermans, B., Van der Toorn, J. and Van Stekelenburg, J. (2008). Embeddedness and grievances: Collective action participation among immigrants. American Sociological Review, 73(6), 992-1012.

Lagroye, J. (1993). Sociologie politique. Paris: Presse de la Fondation Nationale de Sciences Politiques.

Lipset, S.M. (1971). Rebellion in the University. Piscataway, NJ: Transaction Publishers.

Lipset, S.M. and Altbach, P.G. (1967). Student politics and higher education in the United States. In: Lipset, S.M. (ed) Student Politics. New York: Basic Books, 199-252.

Lipsky, M. (1970). Protest in City Politics: Rent Strikes, Housing and the Power of the Poor. Chicago: Rand Mac Nally.

Mannheim, K. (1952). The problem of generations. In: Paul Kecskemeti, P. (ed) Essays on the Sociology of Knowledge. London: Routledge \& Kegan, 276-322.

McAdam, D. (1986). Recruitment to high-risk activism: The case of freedom summer. American of Sociology, 92(1), 64-90.

McAdam, D. (1989). The biographical consequences of activism. American Sociological Review, 54(5), 744-760.

Milbrath, L.W. and Goel, M.L. (1977). Political Participation. Chicago: Rand McNally.

Nepstad, S.E. and Smith, C. (1999). Rethinking recruitment high-risk/cost activism: The case of the Nicaragua Exchange. Mobilisation, 4(1), 25-40.

Nonomura, R. (2016). Political consumerism and the participation gap: Are boycotting and 'buycotting' youth-based activities? Journal of Youth Studies, 20(2), 234-251.

Passy, F. and Giugni, M. (2001). Social networks and individual perceptions: Explaining differential participation in social movements. Sociological Forum, 16(1), 123-153.

Pizzorno, A. (1966). Introduzione allo studio della partecipazione politica. Quaderni di sociologia, 3-4, 235-286. Now in: Pizzorno, A. (1993). Le radici della politica assoluta. Milan: Feltrinelli, 85-128.

Putnam, R.D. (2000). Bowling Alone: The Collapse and Revival of American Community. New York: Simon \& Schuster.

Sander, T.H. and Putnam, R.D. (2010). Still bowling alone? The post-9/11 split. Journal of Democracy, 21, 9-16.

Schussman, A. and Soule, S.A. (2005). Process and protest: Accounting for individual protest participation. Social Forces, 84(2), 1083-1108.

Snow, D. and Lessor, R. (2013). Consciousness, conscience, and social movements. In: Snow, D., della Porta, D., Klandermans, B. and McAdam, D. (eds) Blackwell Encyclopedia on Social and Political Movements. Oxford: Blackwell, 244-249.

van Stakelemburg, J. and Klandermans, B. (2010). The social psychology of protest. Current Sociology, 61(5-6), 886-905.

van Stekelenburg, J., Walgrave, S., Klandermans, B. and Verhulst, J. (2012). Contextualizing contestation: Framework, design and data. Mobilisation, 17(3), 249-262.

Whittier, N. (2001). Emotional strategies: The collective reconstruction and display of oppositional emotions in the movement against child sexual abuse. In: Goodwin, J., Jasper, J.M. and Polletta, F. (eds) Passionate Politics. Chicago: University of Chicago Press, 233-250.

Wiltfang, G.L. and McAdam, D. (1991). The costs and risks of social movement activism: A study of sanctuary movement activism. Social Forces, 69, 987-1010. 